\title{
Phylogenetic analysis of apicomplexan parasites infecting commercially valuable species from the North-East Atlantic reveals high levels of diversity and insights into the evolution of the group
}

\author{
Raquel Xavier ${ }^{1 *}$, Ricardo Severino², Marcos Pérez-Losada ${ }^{1,6}$, Camino Gestal $^{3}$, Rita Freitas ${ }^{1}$, D. James Harris ${ }^{1}$, \\ Ana Veríssimo ${ }^{1,4}$, Daniela Rosado ${ }^{1}$ and Joanne Cable ${ }^{5}$
}

\begin{abstract}
Background: The Apicomplexa from aquatic environments are understudied relative to their terrestrial counterparts, and the seminal work assessing the phylogenetic relations of fish-infecting lineages is mostly based on freshwater hosts. The taxonomic uncertainty of some apicomplexan groups, such as the coccidia, is high and many genera were recently shown to be paraphyletic, questioning the value of strict morphological and ecological traits for parasite classification. Here, we surveyed the genetic diversity of the Apicomplexa in several commercially valuable vertebrates from the NorthEast Atlantic, including farmed fish.

Results: Most of the sequences retrieved were closely related to common fish coccidia of Eimeria, Goussia and Calyptospora. However, some lineages from the shark Scyliorhinus canicula were placed as sister taxa to the Isospora, Caryospora and Schellakia group. Additionally, others from Pagrus caeruleostictus and Solea senegalensis belonged to an unknown apicomplexan group previously found in the Caribbean Sea, where it was sequenced from the water column, corals, and fish. Four distinct parasite lineages were found infecting farmed Dicentrarchus labrax or Sparus aurata. One of the lineages from farmed D. labrax was also found infecting wild counterparts, and another was also recovered from farmed S. aurata and farm-associated Diplodus sargus.
\end{abstract}

Conclusions: Our results show that marine fish apicomplexans are diverse, and we highlight the need for a more extensive assessment of parasite diversity in this phylum. Additionally, parasites recovered from S. canicula were recovered as basal to their piscine counterparts reflecting hosts phylogeny.

Keywords: $18 \mathrm{~S}$ rRNA, Apicomplexa, Goussia, Eimeria, Aquatic pathogens

\section{Background}

Parasites from the phylum Apicomplexa are considered some of the world's most successful parasites, present in most species and responsible for many important diseases [1]. These include Plasmodium species, the causative agents of malaria, and Toxoplasma gondii, which infects most warm-blooded vertebrates and has a high prevalence

\footnotetext{
* Correspondence: raq.xavier@cibio.up.pt

${ }^{1} \mathrm{CIBIO}$, Universidade do Porto, Campus Agrário de Vairão, Rua Padre

Armando Quintas, 4486-661 Vairão, Portugal

Full list of author information is available at the end of the article
}

in humans [2]. Knowledge across the phylum, however, is extremely patchy. Although the Apicomplexa is the largest group of unicellular obligate parasites with more than 6000 described species, these are estimated to correspond to only $0.1 \%$ of the total diversity [1]. Nonetheless, despite their ubiquity and medical/veterinarian importance, the evolutionary history of this group is only now starting to be untangled [3]. Phylogenomic analysis based on 85 proteins indicated that the Apicomplexa evolved from a freeliving ancestor since their sister group was identified as free-living chromerids (photosynthetic) and colpodellids 
(predatory) [4]. Moreover, the Apicomplexa was split into four groups including the most basal cryptosporidean (e.g. Cryptosporidium), followed by the coccidians (e.g. Eimeria, Goussia, Calyptospora and Toxoplasma), and the sister groups of the haemosporidians (e.g. Plasmodium) and piroplasmids (Babesia and Theileria) (see [4]).

Phylogenetic inference based on the $18 \mathrm{~S}$ ribosomal RNA gene (18S rRNA) suggests that the Apicomplexa infecting aquatic organisms form a basal group within the family Eimeriidae [5]. This was confirmed by three pivotal studies which focused on the genetic diversity of fishinfecting coccidia from the genera Eimeria, Goussia and Calyptospora (see [6-8]), that led to the hypothesis that terrestrial counterparts evolved from piscine coccidians. Although some of the hosts included in these previous studies can inhabit brackish waters and some are catadromous, almost all sequenced specimens of Eimeria (see [6]) and Goussia (see [7, 8]) were found infecting hosts collected in freshwater habitats in Hungary. There are only a few exceptions: Fundulus grandis collected from the Gulf coast of the Mississippi [7]), Taurulus bubalis from an unknown locality [6], and Selar crumenophthalmus, Lutjanus kasmira and Mulloidichthys sp. from Hawaii $[8,9]$. For Calyptospora, from the three species for which genetic data are available, only one (C. funduli) was sequenced from a coastal fish ( $F$. grandis; see [8]). The genetic diversity of coccidia infecting fish has been largely neglected; for marine fish there is just a description of an Eimeria sp. from farmed Asian sea bass [10], later identified as Goussia kuehae [11], the genetic characterization of G. clupearum from Atlantic herring [12], and a description of Apicomplexa spp. from Caribbean reef fish (Stegastes spp. and Ophioblennius macclurei) [13].

The taxonomic uncertainty associated with some Eimeria and Goussia species and the paraphyly of both genera has been well studied (e.g. [6, 7]). Although most species described under Eimeria are phylogenetically related (as suggested by $18 \mathrm{~S}$ rRNA data), species of Caryospora (infecting birds and reptiles), Schellakia (infecting reptiles) and Lankesterella (infecting amphibians) are clustered in the same Eimeria clade [6]. The genus Goussia also seems to be paraphyletic and is divided into at least three major groups (sensu Rosenthal et al. [7]): the "dispersed" type (e.g. G. carpelli), found in the gut; the "nodular" type (e.g. G. balatonica), which develop in nodules within the intestine; and the "epicellular" type, present in enterocytes of the gut and kidneys (e.g. Goussia pannonica). Although Calyptospora is estimated to be monophyletic, the genetic data available are still limited (only three sequences, see [8]).

Despite posing a serious threat to aquaculture (e.g. $[14,15])$, there is little information regarding the diversity of coccidian lineages infecting farmed species or farm-associated fish (i.e. those species that enter farms to take advantage of food availability; see [10]). This is surprising given that farming practices can induce increased parasite virulence, for example (i) by selecting for short host lifespan which in turn prompts for accelerated parasite life history (as in the case of Marek's disease in farmed chicken [16]); (ii) high host densities which facilitate transmission (e.g. [17]); (iii) through vaccination and treatment protocols which reduce the disease symptoms rather than eliminate pathogens [18], thereby relaxing competition between parasites and favouring outbreaks of more virulent opportunistic strains [17]; or (iv) through inbreeding depression of stocks which favours the emergence of specialised pathogen strains (see review by [18]).

In this study, we surveyed the genetic diversity and phylogenetic affinities of coccidians infecting wild and farmed fish from the North-East Atlantic. We aim (i) to build upon the limited knowledge regarding the genetic diversity of coccidian parasites infecting marine vertebrates, and (ii) to determine if farmed fish and farm-associated fish species host genetically divergent parasite lineages.

\section{Methods}

Sample collection, DNA extraction and PCR amplification

A total of 148 teleosts and elasmobranchs were bought opportunistically from local fish markets and supermarkets in northern Portugal (Labruge and Vila do Conde): wild $(n=76)$, farmed $(n=38)$ and farm-associated $(n=34)$ (see Table 1 for details). Fish were transported to the laboratory and kept frozen at $-20{ }^{\circ} \mathrm{C}$ until processed. Fish were thawed and dissected, and tissues from internal organs were preserved in 96\% ethanol. For wild teleosts, we screened the following internal organs: intestine, stomach, ovaries/testicles, gall bladder, stomach, liver, kidney, spleen, heart and gills, and for elasmobranchs the liver, stomach, kidney, anal gland and testicles/ovaries. From farmed and farm-associated specimens, only the intestines were analysed. Genomic DNA was extracted from each tissue using Jetquick Tissue DNA Spin Kit (Genomed, Lohne, Germany) following the manufacturer's instructions. The primers published by [19] and designed to amplify Hepatozoon were used in a polymerase chain reaction (PCR) to amplify a $600 \mathrm{bp}$ portion of the $18 \mathrm{~S}$ rRNA gene (HepF300: 5'-GTI TCT GAC CTA TCA GCT TIC GAC G-3'; Hep900 5' -C AAA TCT AAG AAT TIC ACC TCT GAC-3'), following these steps: $3 \mathrm{~min}$ at $94{ }^{\circ} \mathrm{C}$, then 30 cycles of $94{ }^{\circ} \mathrm{C}$ for $30 \mathrm{~s}, 60{ }^{\circ} \mathrm{C}$ for $30 \mathrm{~s}$ and $72{ }^{\circ} \mathrm{C}$ for $30 \mathrm{~s}$; and a final extension at $72{ }^{\circ} \mathrm{C}$ for $7 \mathrm{~min}$. The $18 \mathrm{~S}$ rRNA gene was chosen as is the preferred gene for species identification and phylogenetics of the Apicomplexa as sufficient data are available for comparative purposes (e.g. [7]). PCR master mix reactions were performed using Platinum Taq and a final $\mathrm{MgCl}_{2}$ concentration of $1.5 \mathrm{mM}$. PCR amplicons were sent for sequencing in both directions by a commercial company Genewiz (Takeley, UK). 
Table 1 List of screened hosts, their origin and the number of infected hosts

\begin{tabular}{|c|c|c|}
\hline Host species & Origin & $\begin{array}{l}\text { No. of hosts infected/ } \\
\text { No. of hosts analysed }\end{array}$ \\
\hline Trachurus trachurus & Wild & $2 / 2$ \\
\hline Thunnus sp. & Wild & $1 / 1$ \\
\hline Scomber japonicus & Wild & $1 / 2$ \\
\hline Solea senegalensis & Wild & $2 / 3$ \\
\hline Pagrus caeruleostictus & Wild & $2 / 7$ \\
\hline Trispterus luscus & Wild & $4 / 4$ \\
\hline Sparus aurata & Wild & $0 / 5$ \\
\hline Dicentrarchus labrax & Wild & $1 / 5$ \\
\hline Chelon labrosus & Wild & $0 / 2$ \\
\hline Lepidopus caudatus & Wild & $0 / 1$ \\
\hline Oncorhynchus mykiss & Wild & $0 / 4$ \\
\hline Platichthys flesus & Wild & $0 / 1$ \\
\hline Sardina pilchardus & Wild & $0 / 3$ \\
\hline Dicentrarchus punctatus & Wild & $0 / 1$ \\
\hline Scyliorhinus canicula & Wild & $6 / 33$ \\
\hline Raja undulata & Wild & $0 / 1$ \\
\hline Raja clavata & Wild & $0 / 1$ \\
\hline Dicentrarchus labrax & Farmed & $4 / 22$ \\
\hline Sparus aurata & Farmed & $1 / 16$ \\
\hline Diplodus sargus & Farm-associated & $2 / 5$ \\
\hline Diplodus annularis & Farm-associated & $0 / 1$ \\
\hline Diplodus vulgaris & Farm-associated & $0 / 2$ \\
\hline Chelon labrosus & Farm-associated & $0 / 8$ \\
\hline Halobatrachus didactylus & Farm-associated & $0 / 1$ \\
\hline Sardina pilchardus & Farm-associated & $0 / 1$ \\
\hline Liza ramada & Farm-associated & $0 / 6$ \\
\hline Mugil cephalus & Farm-associated & $0 / 1$ \\
\hline Dicentrarchus punctatus & Farm-associated & $0 / 9$ \\
\hline
\end{tabular}

All new sequences were submitted to the GenBank database (accession nos. MF468290-MF468328).

\section{Sequence alignment and phylogenetic analysis}

Sequences were checked manually using the software Geneious v4.8.5 [20] and compared against the GenBank database to confirm whether they belonged within the Apicomplexa. Following the criteria of Rosenthal et al. [7] only those sequences with clean chromatograms were included for analysis. All alignments were performed using MAFFT v7 [21], and the software JModeltest v2.2.1 [22] was used to select the appropriate model of evolution (AIC criteria). Phylogenetic reconstruction analyses based on Maximum Likelihood (ML) and Bayesian Inference (BI) were conducted using Garli v2.1 [23] and MrBayes v3.2.6 [24], respectively.
First, a phylogenetic analysis was conducted including 40 newly generated sequences, plus $18 \mathrm{~S}$ rRNA gene sequences of coccidians retrieved using the BLAST algorithm against the GenBank database (e.g. apicomplexans infecting corals) and sequences of piscine apicomplexans (included for example in the analyses of [6-8]). Separate phylogenetic analyses were conducted for subsets of related sequences identified in the preliminary analysis to improve alignment quality and outgroup choice. Two parallel runs were conducted for all analyses in MrBayes. In the first preliminary dataset runs were set to 30 million generations, and in the other subsequent analyses to 10 million. The software Tracer v1.6 [25] was used to check for adequate mixing and convergence of each run. Trees from a stationary distribution ( $25 \%$ 'burn-in') were used to construct a majority rule consensus tree. For the ML analyses, 1000 bootstraps were used to evaluate branching support. Uncorrected p-distances were calculated for each group using the software MEGA6 [26] to evaluate interspecific divergence and draw taxonomic conclusions.

\section{Results}

Clean nucleotide sequences were derived from apicomplexans collected from multiple organs of nine hosts, including the elasmobranch Scyliorhinus canicula (summarised in Table 2). The sequence retrieved from the intestine of Thunnus sp. was only $277 \mathrm{bp}$ and was not included in the phylogenetic analysis; however, it was identical to sequences of Eimeriidae gen. sp. retrieved from Trisopterus luscus (see Table 2). The remaining sequence was too noisy, probably due to length variants of ribosomal copies, multiple infections or contamination with other organisms (e.g. fungi). Similarly, amplification but noisy sequences were obtained for samples collected from the intestine of S. senegalensis, the kidney of $P$. caeruleostictus, liver of $S$. japonicus, gall bladder and stomach of $T$. thunnus, gills of $T$. luscus, the gills, liver, kidney, spleen and stomach of D. labrax, kidney of $S$. aurata, and the spleen of O. mykiss. The final alignment (including all sequences generated plus relevant sequences deposited on GenBank) was trimmed to $628 \mathrm{bp}$ (including gaps), and was analysed using the GTR + I + G model of evolution. This analysis indicated that the sequences obtained in this study could be divided into five major groups (Additional file 1: Figure S1 and Additional file 2: Figure S2): Goussia spp., Eimeria spp., Calyptospora spp., a fourth group including species of Caryospora, Isospora, Schellakia and Eimeria, so far only known to infect amphibians, reptiles, birds and mammals; and, finally, a group of yet unknown apicomplexans. Due to the high diversity and divergence of taxa included in this analysis which limited phylogenetic resolution, additional phylogenetic analyses were performed separately for subsets of sequences representative of these groups, including only unique haplotypes. Sequences for Eimeria spp. and 
Table 2 List of infected hosts, infected tissues, phylogenetic affinities of the parasites found and GenBank ID. All hosts have wild origin unless indicated otherwise

\begin{tabular}{|c|c|c|c|}
\hline Host species & Infected organ & Parasite & GenBank ID \\
\hline Diplodus sargus $^{a}$ & Intestine & Goussia sp. (Fig. 1, Additional file 1: Figure S1) & MF468321 \\
\hline Sparus aurata ${ }^{\mathrm{b}}$ & Intestine & Goussia sp. (Fig. 1, Additional file 1: Figure S1) & MF468322 \\
\hline Scomber japonicus & Heart, kidney & Goussia sp. (Fig. 1, Additional file 1: Figure S1) & MF468319, MF468320 \\
\hline \multirow[t]{2}{*}{ Dicentrarchus labrax ${ }^{b}$} & Intestine & Goussia sp. (Fig. 1, Additional file 1: Figure S1) & MF468318 \\
\hline & Intestine & $\begin{array}{l}\text { Eimeria cf. variabilis (Fig. 2, Additional file 2: Figure S2); } \\
\text { Eimeria sp. (Fig. 2, Additional file 2: Figure S2) }\end{array}$ & MF468291, MF468292 \\
\hline Dicentrarchus labrax & Intestine & Eimeria sp. (Fig. 2, Additional file 2: Figure S2) & MF468293 \\
\hline \multirow[t]{2}{*}{ Trisopterus luscus } & Intestine & Eimeria sp. (Fig. 2, Additional file 2: Figure S2) & MF468290 \\
\hline & $\begin{array}{l}\text { Stomach, gall bladder, liver, } \\
\text { heart, spleen, intestine }\end{array}$ & Eimeriidae gen. sp. (Fig. 2, Additional file 2: Figure S2) & MF468299-MF468308 \\
\hline Trachurus trachurus & Intestine, liver, spleen, stomach & Eimeriidae gen. sp. (Fig. 2, Additional file 2: Figure S2) & MF468309-MF468314 \\
\hline \multirow[t]{3}{*}{ Scyliorhinus canicula } & Liver & Eimeriidae gen. sp. (Fig. 2, Additional file 2: Figure S2) & MF468294 \\
\hline & Liver & Eimeria sp. (Fig. 2, Additional file 2: Figure S2) & MF468298 \\
\hline & Liver, anal gland, stomach & Coccidia sp. (Fig. 3, Additional file 2: Figure S2) & MF468295-MF468297 \\
\hline \multirow[t]{2}{*}{ Pagrus caeruleostictus } & Gall bladder, liver, intestine & Calyptospora sp. (Fig. 2, Additional file 2: Figure S2) & MF468315-MF468317 \\
\hline & Heart, kidney & Apicomplexa fam. gen. sp. (Fig. 4, Additional file 1: Figure S1) & MF468323, MF468324 \\
\hline Thunnus sp. & Intestine & Eimeriidae gen. sp. & MG724744 \\
\hline Solea senegalensis & Testes, liver, gills & Apicomplexa fam. gen. sp. (Fig. 4, Additional file 1: Figure S1) & MF468325-MF468328 \\
\hline
\end{tabular}

${ }^{\mathrm{a}}$ Farm-associated hosts

${ }^{\mathrm{b}}$ Farmed hosts

'The sequence obtained from the parasite infecting Thunnus sp. was not used in the phylogenetic analysis due to its short length

Calyptospora spp. are usually recovered in phylogenetic analyses as closely related (e.g. [8]), and for this reason, were merged in the same analysis.

The Goussia spp. sequence alignment was 510 bp and was analysed using the HKY + I + G model of evolution. The resultant phylogram is depicted in Fig. 1 and included sequences from the heart and kidney of $S$. japonicus, the intestine of farmed D. labrax and Sparus aurata, and farm-associated Diplodus sargus. The Eimeria spp. and Calyptospora spp. alignment included $627 \mathrm{bp}$ and was analysed using the HKY $+\mathrm{I}+\mathrm{G}$ model of evolution. This phylogram showed two sequences retrieved from S. canicula as basal in relation to sequences for other Eimeriidae (Fig. 2). Sequences from parasite lineages found in several organs of T. luscus, T. trachurus and P. caeruleostictus formed a well-supported clade also containing Calyptospora species, with the latter two being recovered as sister lineages with high bootstrap support (99\% posterior probability and 100 bootstrap support). Additionally, the sequence from a parasite found in the intestine of T. luscus as well as sequences obtained from parasites in intestines of farmed D. labrax, were closely related to Eimeria species found in the gut of other fish species (Fig. 2). The fourth group alignment, herein designated as Caryosporalike for the sake of simplicity, contained $512 \mathrm{bp}$ and was analysed using the GTR + I + G model of evolution. The resulting phylogram showed the sequences from $S$. canicula forming a well-supported clade which was basal in the group (Fig. 3). Finally, for the unnamed Apicomplexa, the alignment included $524 \mathrm{bp}$ and used the HKY + G model of evolution. This phylogram showed that some parasite genotypes found in P. caeruleostictus and S. senegalensis formed a clade that included parasite found in a reef fish and also in the water column of the Caribbean Sea (Fig. 4). This clade appeared as the sister group to several parasite lineages found in corals from the same region (Fig. 4).

The uncorrected p-distances calculated for sequence pairs in each group are presented in supplementary material (Additional file 3: Tables S1-S5). This genetic distance was chosen to allow comparisons across all taxonomic groups. Based on these results, and on the minimum and maximum divergence found between two accepted species in each group, we determined if each new sequence likely corresponded to a species or simply to a lineage within a species. For example, the divergence between accepted species of Goussia varied between $0.4-5.8 \%$, so the lineages found in S. japonicus and D. labrax likely belong to three different species (minimum p-distance $=0.4 \%$, see Additional file 3: Table S1). On the other hand, sequences of Goussia spp. recovered from the intestines of D. sargus and $S$. aurata were identical and likely corresponded to a single species different from the species for which data are currently available ( $\mathrm{p}$-distance between this lineage and other sequenced species varied between 2.2-5.8\%). Divergence 


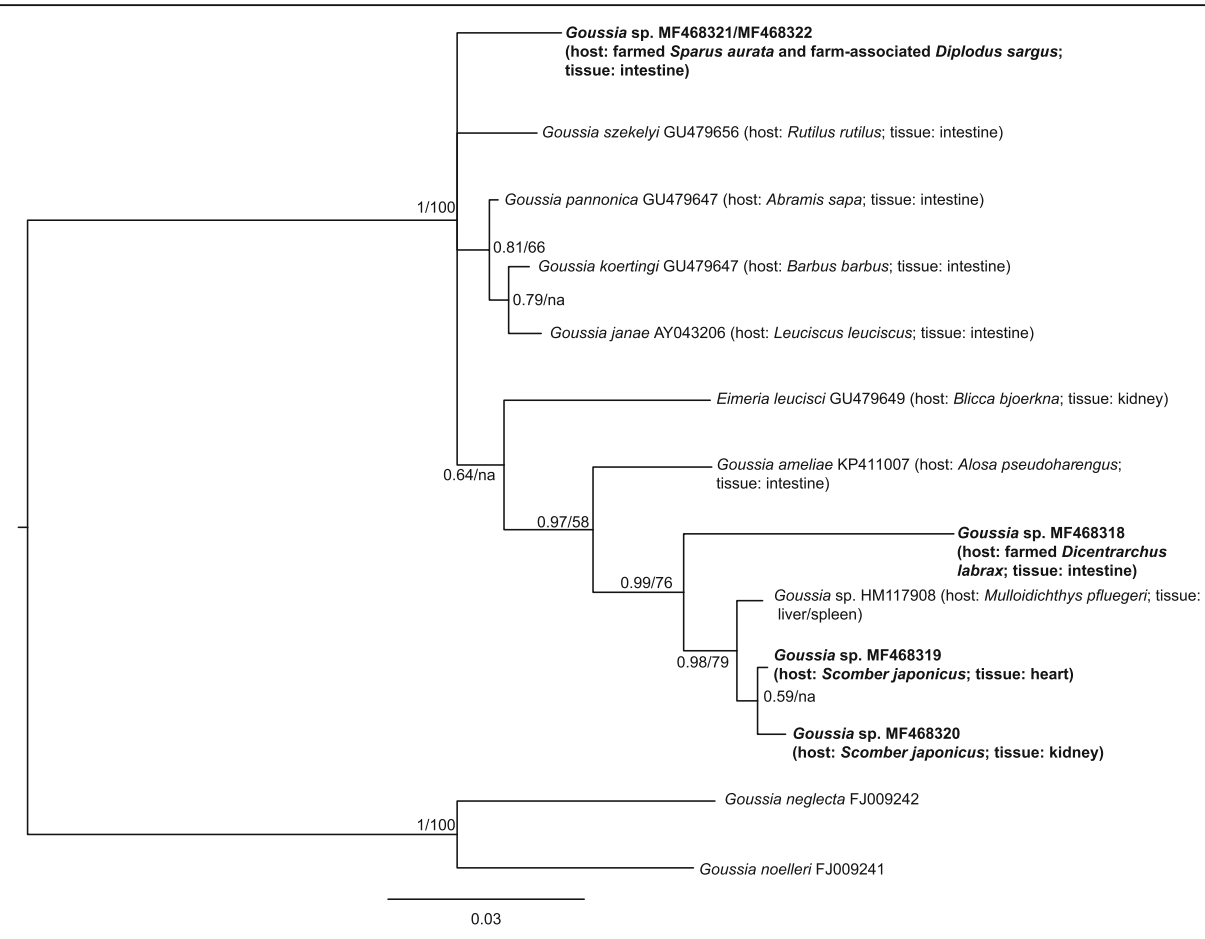

Fig. 1 Bayesian inference analysis based on sequences for epicellular Goussia sensu Rosenthal et al. [7]. Node support values correspond to posterior probabilities and consensus support (\%) obtained from Bayesian inference and Maximum Likelihood analyses, respectively. The newly generated sequences are indicated in bold. Only unique haplotypes were included in the analysis

between the three previously sequenced Calyptospora species ranged between 5.2-7.2\% (Additional file 3: Table S2), which led us to consider that the lineages from T. trachurus may belong to a single species (p-distance ranged between $0.2-$ $1.2 \%$ ), as well as the lineages found in P. caeruleostictus (pdistance ranged between 0.2-0.4\%) and T. luscus (p-distance ranged between 0 and 1.9\%). In the Eimeria group, the pdistance found between accepted Eimeria species included in our analysis ranged between 4.0-11.2\%. However, Eimeria species described from birds, for which more data are available, can diverge by less than $1 \%$, so these sequences could be from other species (e.g. E. tenella and E. necatrix deposited on GenBank under accession numbers KT184354 and DQ136185). Accordingly, although two of the lineages found in D. labrax were related with $E$. percae (p-distance varied between $1.3-1.4 \%$ ), it is likely they belong to a different species, whereas a third lineage recovered from wild and farmed $D$. labrax likely corresponds to $E$. variabilis (p-distance of $0.6 \%$ ). The apicomplexans sequenced from S. canicula were basal in the phylogeny so we cannot ascertain if they belong to the genus Eimeria or a close relative; however, they correspond to two different species ( $\mathrm{p}$-distance between them of 8.5\%), also quite distinct from the taxa included in our analysis (minimum distance of $8.8 \%$ ). In the unknown clade, it is more difficult to establish a criterion to determine species as taxa remain unclassified. However, taking into account the previous criteria the lineages in $P$. caeruleostictus may correspond to the same species (p-distance of $0.2 \%$ ), as do the lineages found in S. senegalensis (p-distance ranged between $0-0.8 \%$ ).

\section{Discussion}

The estimates of $18 \mathrm{~S}$ rRNA phylogenetic relationships proposed in this study are similar to those previously published for these apicomplexan fish pathogens. Briefly, the epicellular Goussia (Fig. 1) forms a distinct group, positioned as basal in relation to other Goussia groups [7], and members of Caryospora, Isospora (both Eimeriidae) and Schellakia (Schellakiadae) are closely related [27-29]. Previously, Eimeria spp. from fish and other hosts were placed within the same clade [6,7], whereas in the current study fish-infecting Eimeria formed a distinct clade (Additional file 1: Figure S1; Additional file 2: Figure S2). In our opinion, this discrepancy is due to differences in the 18S rRNA gene fragments employed and the wider range of taxa in our analysis, including members from an undescribed Apicomplexa group.

The criteria used here to consider as putative species the lineages with less divergence (based on p-distance) than the minimum calculated between accepted species, implies that Eimeria cf. variabilis was encountered in D. labrax (see Fig. 2). Although sequence data are becoming essential tools for studying the Apicomplexa (e.g. [7, 30-33]), the strict use of molecular data for species identification can be 


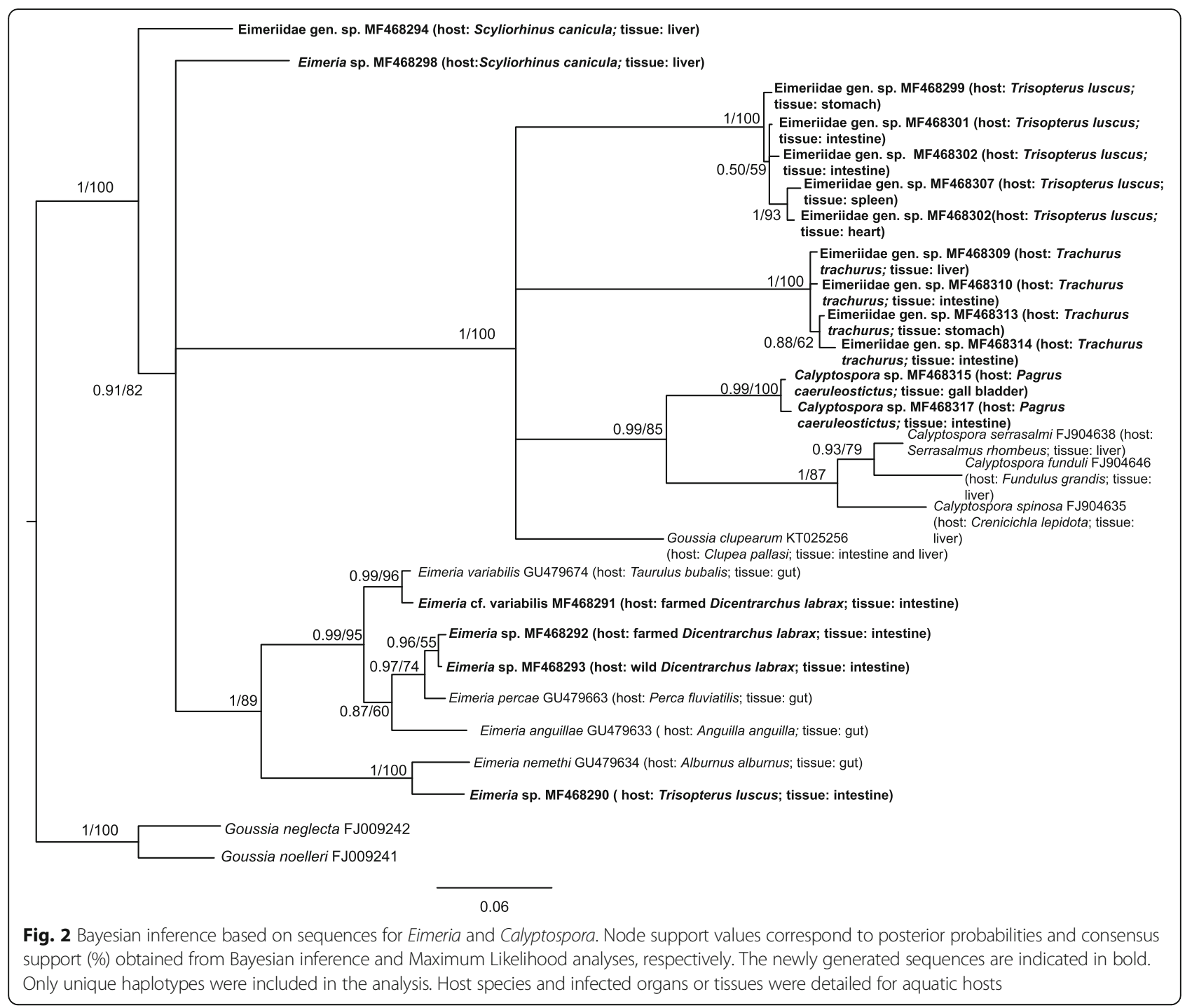

hampered in the absence of morphological characterisation and requires this results should be interpreted with caution (e.g. [34]). Additionally, the $18 \mathrm{~S}$ rRNA gene was shown to have limited resolution in Eimeria species discrimination in comparison with the mitochondrial cytochrome $c$ oxidase subunit 1 gene [30]. In this respect, ours is a conservative approach based on marker choice.

Our data also showed that potential intraspecific variation can be high. For example, divergence between the genotypes in T. trachurus reached $1.2 \%$ and those infecting T. luscus reached $1.9 \%$. This is in line with previous results [8] where intraspecific variation could be as high as $4.2 \%$ in Calyptospora spinosa. Divergent $18 \mathrm{~S}$ rRNA paralogs have also been reported to occur within other coccidian species (e.g. 1.31.7\% for Eimeria mitis [35]; Plasmodium spp. [36]) and even within individuals (Eimeria meleagrimitis, 2.3\% [37]). However, many studies have shown that the existence of paralogs are not common, but rather the exception $[38,39]$.
Regarding the differentiation of wild $v s$ fish-farm infecting lineages, only two of the four parasites infecting famed fish, i.e. one Eimeria sp. and one Goussia sp. (Figs. 1 and 2), were exclusively found in fish farms. A third parasite lineage, likely Eimeria cf. variabilis, was recovered in farmed and reported from wild D. labrax; and a Goussia sp. infected both farmed $S$. aurata and farm-associated $D$. sargus. Although this is speculative as both $S$. aurata and $D$. sargus can be natural reservoirs for this parasite, spillover may be occurring from wild to farmed hosts since this parasite was found in only one individual of $S$. aurata, out of 16 analysed hosts, and in two farm-associated D. sargus, out of 5 individuals analysed ( 2 out of 5 ).

\section{Epicellular Goussia parasitic lineages infecting fish from the North-East Atlantic}

Four genotypes closely related with epicellular Goussia species sensu Rosenthal et al. [7] were recovered among 


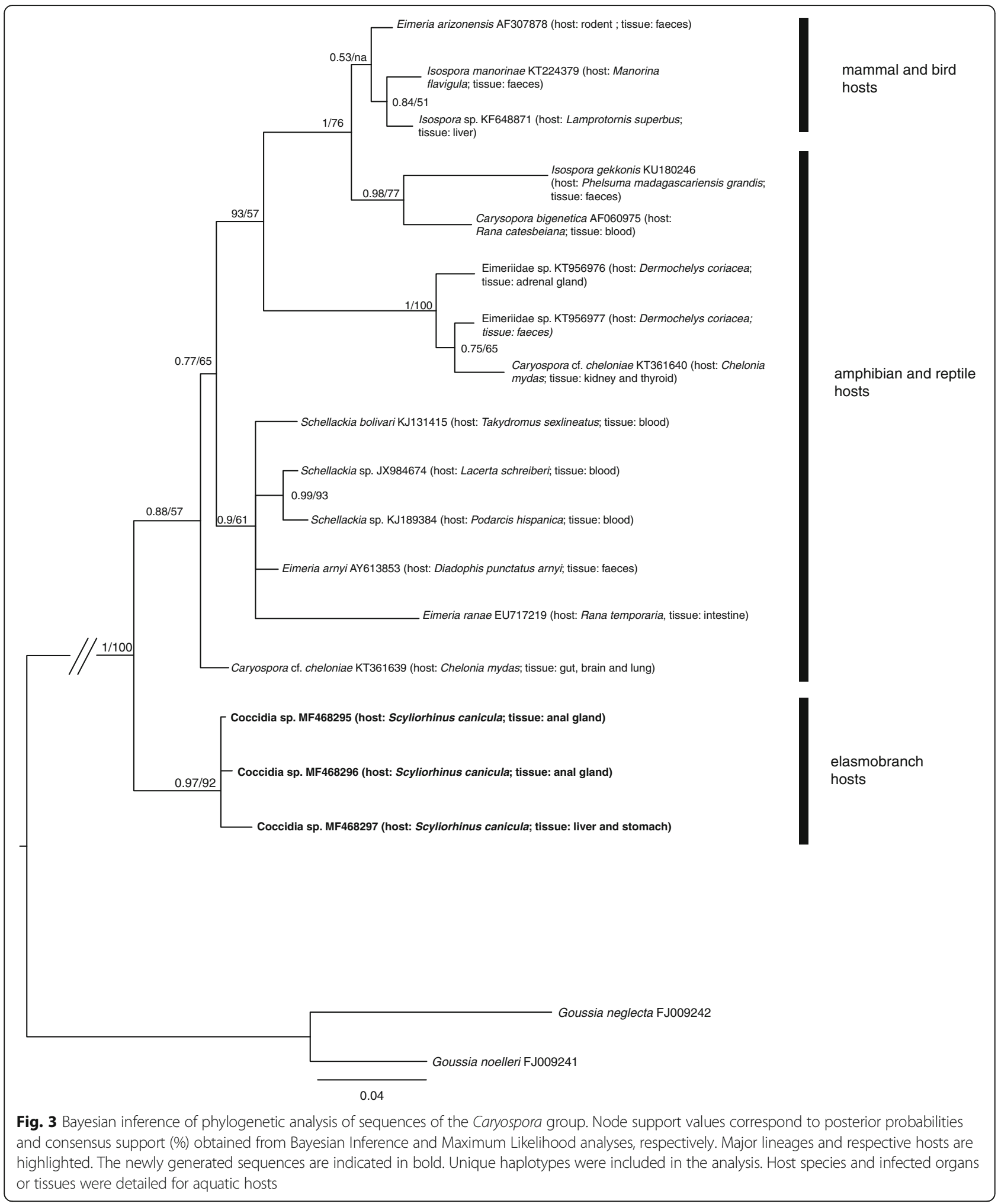

the analised fish. According to the genetic distances within this Goussia group (where interspecific distances range between 0.4-4.4\%), the genotypes found in Scomber japonicus, Dicentrarchus labrax and Sparus aurata+
Diplodus sargus could correspond to different species as genetic distances between them ranged between $0.4-7.3 \%$. To the best of our knowledge, besides G. clupearum there are no records of other coccidia infecting Diplodus spp. 


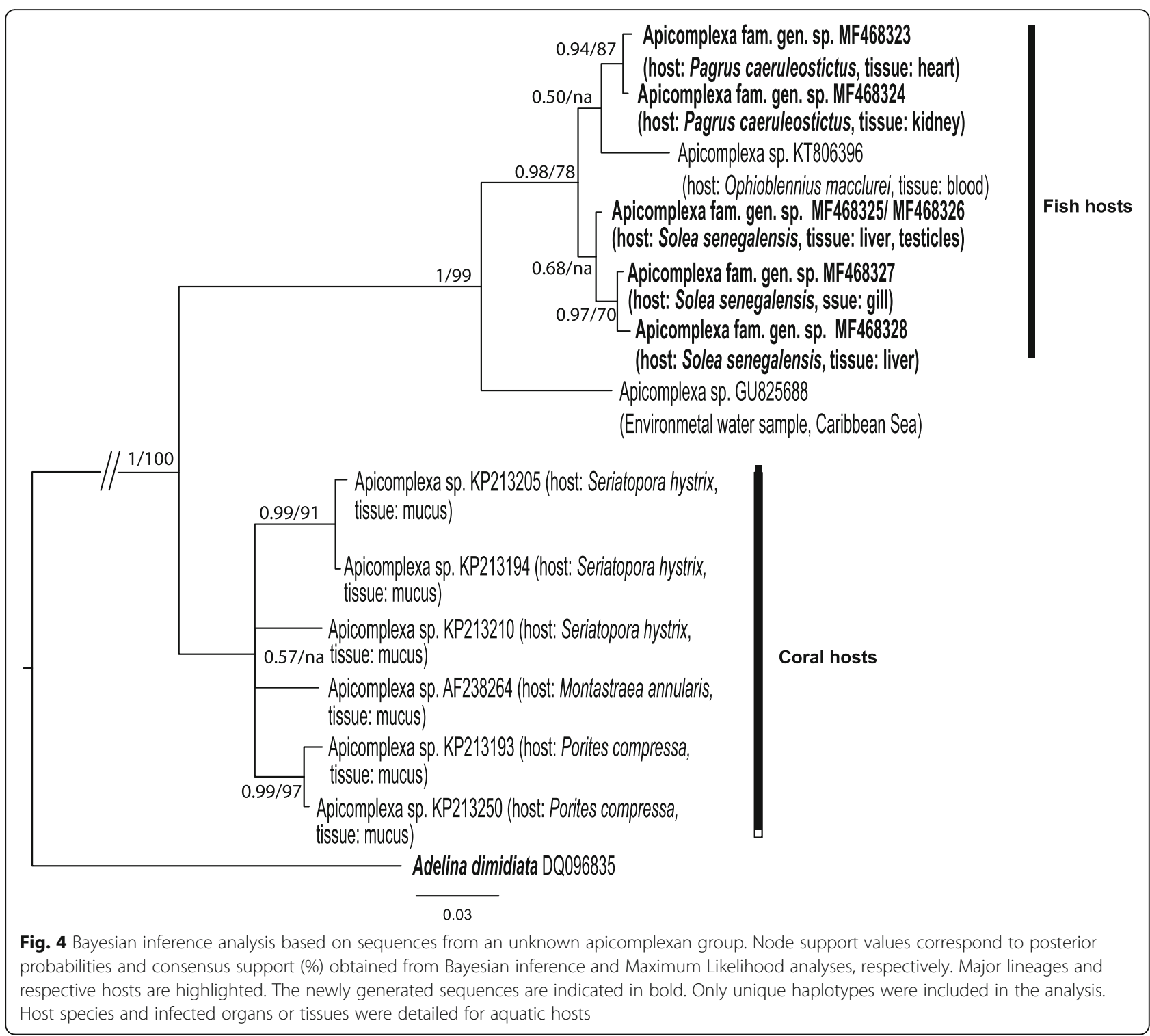

On the other hand, both Goussia sparis and Eimeria spari have been described from the intestine of $S$. aurata; hence, the genotypes retrieved could correspond to any of these parasites.

The species found in S. japonicus were closely related to another coccidian species described from the spleen and kidneys of Lutjanus kasmira, Selar crumenophthalmus and Mulloidichthys sp. in Hawaii (only 0.4\% divergence, see [8] and [11]), which Whipps et al. [8] suggested to belong to Goussia. The morphology of this putative Goussia sp. is very similar to that of the coccidian infecting the kidney of S. aurata from the Red Sea (originally reported as an haemogregarine [40]) and a Liza host species from Africa (also reported as an haemogregarine [41]), suggesting that this putative Goussia sensu Whipps et al. [8], might have a wide host and geographical range. Although the Goussia found in S. japonicus could belong to a distinct Goussia species, the levels of divergence between the two are at the lower interval of the observed interspecific divergence for this group.

\section{Eimeria, Calyptospora and other related parasites} infecting fish from the North-East Atlantic

Phylogenetically, Eimeria and Calyptospora are closely related genera often recovered as sister clades [6, 8]. However, their phenotypes and life-traits are quite distinct (e.g. [42]). While Eimeria spp. are mostly described to infect the gut of fish, although with a few exceptions $[6,7]$, Calyptospora infects the liver of their hosts (e.g. [8]). Here, we found three genotypes that likely correspond to three Eimeria spp., in the intestine of two in D. labrax and one in T. luscus. One of the Eimeria sp. infecting D. labrax is 
likely to correspond to Eimeria variabilis as it was only $0.6 \%$ divergent from one sequenced from a Taurulus bubalis sampled off the United Kingdom. The other lineages of Eimeria were obtained from D. labrax, and are closely related to Eimeria percae (minimum 0.13\% divergence) from the freshwater host Perca fluviatilis captured from freshwater habitats in Hungary [7]. So far, only two Eimeria species are reported from the intestine of D. labrax: E. dicentrarchi from wild and farmed fish (e.g. [43, 44]) and E. bouixi [44]. However, there are also reports of an unidentified Eimeria species in the intestine of wild D. labrax off the coasts of Portugal [45]. As such, the lineages here detected could also correspond to these species.

The Eimeria sp. sequenced from T. luscus is related to Eimeria nemethi (4.4\% divergence) detected in the freshwater host Alburnus alburnus captured in Hungary [7]. Additionally, we found other divergent parasite genotypes infecting the heart, stomach, spleen and intestine of T. luscus, which based on our data are more closely related to Calyptospora and Goussia clupearum, originally described as Eimeria clupeaurum, sequenced from Clupea pallasii. Similarly, in T. trachurus several parasitic genotypes, recovered as closely related with Calyptospora and G. clupearum, were found in host liver, stomach and intestine. The phylogenetic proximity of $G$. clupearum with Calyptospora has already been reported by Friend et al. [12] and confirms the high taxonomic uncertainty associated with members of Goussia. So far, Goussia lusca is the only coccidian parasite reported to infect $T$. luscus, and this parasite shares morphological similarities in some developmental stages with $G$. clupearum (see [46]). However, the liver seems to be the only tissue affected by G. lusca. In turn, G. clupearum has been described from several hosts including $T$. trachurus captured off the Galician coast (Spain) [47], and other Trisopterus species (e.g. off Scotland [48]). Despite the considerable morphological variation found in G. clupearum from different hosts (see [46]), which could indicate the existence of a species complex, infections by G. clupearum seem to be restricted to host liver. In $T$. trachurus, besides G. clupearum, another extraintestinal parasite, Goussia cruciata (originally described as Eimeria cruciata) has been reported at high prevalence from this fish species in the Alboran Sea [49] and North-East Atlantic [47]. Goussia cruciata has a broader tissue tropism, infecting multiple organs (liver, intestine and pancreas, e.g. $[50,51])$. As such it is possible that the parasite lineages retrieved from $T$. trachurus in the present work correspond to this species. This uncertainty might be resolved with morphological characterization of these parasites.

The genotypes sequenced from Pagrus caeruleostictus were recovered in the present phylogenetic analysis as sister to the genus Calyptospora. To the best of our knowledge, the only coccidians known to infect this fish belong to Eimeria (e.g. [52]). Although the divergence between the genotypes found in $P$. caeruleostictus and Calysptospora spp. ranges between 0.9-11.0\%, i.e. above the observed divergence between Calyptospora spp. (5.7-7.2\%), the monophyly of the clade was highly supported ( $99 \%$ posterior probability and 100 bootstrap support); for this reason we considered the genotypes recovered from $P$. caeruleostictus likely to belong to Calyptospora.

Some of the parasites found infecting the liver of S. canicula were also related to Eimeria. So far Eimeria lucida is the only coccidian described to infect Scyliorhinus canicula, as well as other elasmobranchs. Hence the Eimeria sp. and the Eimeriidae gen. sp. sequences recovered for this host herein, may correspond to E. lucida.

\section{The Apicomplexa infecting Scyliorhinus canicula are closely related with the Eimeriidae and Schellakiidae infecting reptiles, amphibians and birds}

Some of the Apicomplexa sequenced from S. canicula were recovered in the present phylogenetic analysis as sister to coccidia from the Eimeriidae (Isospora, Caryospora) and Schellakiidae (Schellakia) that infect amphibians and reptiles, including marine turtles (Fig. 3). Given the phylogenetic affinities of the available sequences attributed to Caryospora cheloniae, (herein designated as Caryospora cf. cheloniae), it has been suggested that the taxonomy of this parasite should be redefined and that it should be placed in a different genus [29]. Likewise, the genetic divergence between the sequences recovered from $S$. canicula and their relatives also suggests that these should be part of a new genus.

Interestingly, the results we obtained for the phylogeny of these parasite groups match the estimates of host phylogenetic relationships, as elasmobranchs are one of the oldest vertebrates sharing a common ancestor with amphibians, reptiles plus birds and mammals (e.g. [53]). However to confirm this hypothesis more molecular data regarding Apicomplexa infecting fishes and elasmobranchs is needed.

\section{Undescribed diversity of the Apicomplexa in the marine realm}

The work of Janouškovec et al. [4] highlighted the understudied nature of marine and freshwater environments in terms of the Apicomplexa and other related parasites. In the present study, the parasites found in Solea senegalensis and Pagrus caeruleostictus were close relatives of an apicomplexan from the blood of a Caribbean fish (Ophioblennius macclurei, see [13]) and also of a parasite sequenced from an eDNA seawater sample from the Caribbean [54]. These sequences were in turn sister to an unnamed clade composed of parasites recovered from the mucous of several Caribbean corals (see the supplementary material in [4]). The phylogeny of Janouškovec et al. 
[4] identified these coral-dwelling lineages as sister to Sarcocystis and eimeriids, and the authors suggested that they remained undescribed because coral reefs are poorly surveyed for the Apicomplexa. Here we demonstrate that relatives of the lineages found by Janouškovec et al. [4] parasitise common and commercially valuable fish, thus confirming the understudied nature of this parasite group in the marine realm. Morphological data will help clarify the taxonomy of these parasites, but this requires fresh tissue which was not compatible with our sampling strategy.

\section{Conclusions}

Here we demonstrate that the Apicomplexa infecting marine fish, which could be separated into five distinct groups according to their phylogenetic affinities. Three of these, Goussia, Eimeria and Calyptospora, are common coccidian parasites of fish. Another group was related to the genera Caryospora (Eimeriidae), Schellakia (Schellakiidae) and Isospora (Eimeriidae), which typically infect terrestrial vertebrates (e.g. [55]). Lastly, a set of sequences were placed in an unknown group of the Apicomplexa so far only recovered from the Caribbean Sea, having been found in the mucus of corals [4], an environmental sample from the water column [54], and a fish [13]. Additionally, our phylogenetic results suggest that the Apicomplexa recovered from elasmobranchs are basal, which is in line with the host's phylogenetic relationships since elasmobranchs (together with the holocephalans) are the oldest jawed vertebrates on earth (e.g. [56]).

\section{Additional files}

Additional file 1: Figure S1. Bayesian inference analysis of epicellular Goussia spp. and the unknown apicomplexan clade based on sequences generated in the present study plus previously public sequences retrieved from GenBank. The newly generated sequences are depicted in bold. Host species and infected organs or tissues were detailed for all aquatic hosts. (EPS $3990 \mathrm{~kb}$ )

Additional file 2: Figure S2. Bayesian inference analysis of dispersed and nodular Goussia, Caryospora-, Calyptospora- and Eimeria-like sequences generated in the present study, plus previously published or public sequences retrieved from GenBank. Node support values correspond to posterior probabilities and consensus support (\%) obtained from Bayesian inference and Maximum Likelihood analyses, respectively. The major phylogenetic groups infecting aquatic hosts are highlighted according to the legend, and the newly generated sequences are indicated in bold. Host species and infected organs or tissues were detailed for all aquatic hosts. (EPS $3133 \mathrm{~kb}$ )

Additional file 3: Table S1. Uncorrected p-distances estimated between pairs of samples fror the Goussia group. Sequences generated in the present study are highlighted in bold, as well as p-distances between them. Organs from where the sequences were retrieved were coded as follows: ${ }^{*}$ intestine, 1 gall bladder, 「 liver,tstomach, łspleen, $\cdot$ heart, a kidney. Table S2. Uncorrected p-distances between pairs of sequences from the Calyptospora group. Sequences generated in this study are highlighted in bold, as well as p-distances between them. Organs from where the sequences were retrieved were coded as follows: * intestine, 7 gall bladder, $\Gamma$ liver, $\neq$ spleen, $\bullet$ heart, a kidney. Table S3. Uncorrected p-distances between pairs of sequences from the Eimeria group. Sequences generated in this study are highlighted in bold, as well as p-distances between them. All sequences were obtained from the intestines (coded as *) or liver (coded as Г). Table S4. Uncorrected p-distances between pairs of sequences in the Caryospora, Shellackia and Isospora group. Sequences generated in this study are highlighted in bold, as well as p-distances between them. Organs from where the sequences were retrieved were coded as follows: *anal gland, $\Gamma$ liver,tstomach. Table S5. Uncorrected p-distances between pairs of sequences in the Unknown Apicomplexa group. Sequences generated in this study are highlighted in bold, as well as p-distances between them. Organs from where the sequences were retrieved were coded as follows: * intestine, 1 gall bladder, $\Gamma$ liver,tstomach, ¥spleen, $\bullet$ heart, a kidney, $\phi$ testicle, $¥$ gill. (DOCX $38 \mathrm{~kb})$

\section{Acknowledgements}

We thank Pedro Cardoso and Carlota Silva for help in processing S. canicula samples.

\section{Funding}

This work was partially funded by the European Regional Development Fund (ERDF) through COMPETE program and by National Funds through FCT Foundation for Science and Technology (EXPL/MAR-BIO/1034/2012, PTDC/MARBIO/4458/2012 and FCOMP-01-0124-FEDER- 029939, PTDC/MAR-BIO/0902/2014 and POCl-01-0145-FEDER-016550); and partially funded by Norte Portugal Regional Operational Programme (NORTE 2020), under the PORTUGAL 2020 Partnership Agreement and through ERDF under project Marlnfo. RX, MPL, DJH and AV are supported by FCT under the Programa Operacional Potencial Humano - Quadro de Referência Estratégico Nacional funds from the European Social Fund and Portuguese Ministério da Educação e Ciência (RX: IF/00359/2015; MPL: IF/00764/ 2013; DJH: IF/01627/2014; AV post-doctoral Grant SFRH/BPD/77487/2011).

\section{Availability of data and materials}

The data supporting the conclusions of this article are included within the article and its additional files. The sequences generated in this study were submitted to the GenBank database under the accession numbers MF468290-MF468328 and MG724744.

\section{Authors' contributions}

RX, RS, JC, CG and MPL designed the study. RS, RX, AV and DJH collected the samples. RX, RF and DR conducted laboratory work. RX performed the phylogenetic analyses. RX, CG, JC, MPL and DJH drafted the manuscript. All authors read and approved the final manuscript.

\section{Ethics approval and consent to participate}

Not applicable.

\section{Consent for publication}

Not applicable.

\section{Competing interests}

The authors declare that they have no competing interests.

\section{Publisher's Note}

Springer Nature remains neutral with regard to jurisdictional claims in published maps and institutional affiliations.

\section{Author details}

${ }^{1} \mathrm{CIBIO}$, Universidade do Porto, Campus Agrário de Vairão, Rua Padre Armando Quintas, 4486-661 Vairão, Portugal. ${ }^{2}$ Piscicultura Vale da Lama, Sapal do Vale da Lama, Odiáxere, Lagos 8600-258, Nigeria. ${ }^{3}$ Instituto de Investigaciones Marinas, Consejo Superior de Investigaciones Científicas (IIM-CSIC), Eduardo Cabello, 6, 36208 Vigo, Spain. ${ }^{4}$ Virginia Institute of Marine Science, College of William and Mary, Route 1208, Greate Road, 23062 Gloucester Point, Virginia, USA. ${ }^{5}$ School of Biosciences, Cardiff University, Cardiff CF10 3AX, UK. 'Department of Invertebrate Zoology, US National Museum of Natural History, Smithsonian Institution, Washington, DC 20013, USA. 
Received: 21 April 2017 Accepted: 15 January 2018 Published online: 25 January 2018

\section{References}

1. Morrison DA. Evolution of the Apicomplexa: where are we now? Trends Parasitol. 2009;25:375-82

2. Jones JL, Kruszon-Moran D, Wilson M, McQuillan G, Navin T, McAuley JB. Toxoplasma gondii infection in the United States: seroprevalence and risk factors. Am J Epidemiol. 2001;154:357-65.

3. Arisue N, Hashimoto T. Phylogeny and evolution of apicoplasts and apicomplexan parasites. Parasitol Int. 2015;64:254-9.

4. Janouškovec J, Tikhonenkov D, Burki F, Howe A, Kolisko M, Mylnikov A, Keeling P. Factors mediating plastid dependency and the origins of parasitism in apicomplexans and their close relatives. Proc Natl Acad Sci USA. 2015;112:10200-7.

5. Jirků M, Jirků M, Oborník M, Lukes J, Modry D. Goussia Labbé, 1896 (Apicomplexa, Eimeriorina) in Amphibia: diversity, biology, molecular phylogeny and comments on the status of the genus. Protist. 2009;160:123-36.

6. Molnár K, Ostoros G, Dunams-Morel D, Rosenthal B. Eimeria that infect fish are diverse and are related to, but distinct from, those that infect terrestria vertebrates. Infect Genet Evol. 2012;12:1810-5.

7. Rosenthal BM, Dunams-Morela D, Ostoros G, Molnár K. Coccidian parasites of fish encompass profound phylogenetic diversity and gave rise to each of the major parasitic groups in terrestrial vertebrates. Infect Genet Evol. 2016;40:219-27.

8. Whipps CM, Fournie JW, Morrison DA, Azevedo C, Matos E, Thebo P, Kent M. Phylogeny of fish-infecting Calyptospora species (Apicomplexa: Eimeriorina). Parasitol Res. 2012;111:1331-42.

9. Work TM, Rameyer RA, Takata G, Kent ML. Protozoal and epitheliocystis-like infections in the introduced bluestripe snapper Lutjanus kasmira in Hawaii. Dis Aquat Org. 2003;57:59-66

10. Gibson-Kueha S, Thuy NTN, Elliot A, Jones JB, Nicholls PK, Thompson RCA. An intestinal Eimeria infection in juvenile Asian seabass (Lates calcarifer) cultured in Vietnam - a first report. Vet Parasitol. 2011;181:106-12.

11. Székely C, Borkhanuddin MH, Shaharom F, Embong MSA, Molnár K Description of Goussia kuehae n. sp. (Apicomplexa: Eimeriidae) infecting the Asian seabass, Lates calcarifer (Bloch) (Perciformes: Latidae), cultured in Malaysian fish farms. Syst Parasitol. 2013;86:293-9.

12. Friend SE, Lovy J, Hershberger P. Disease surveillance of Atlantic herring: molecular characterization of hepatic coccidiosis and a morphological report of a novel intestinal coccidian. Dis Aquat Org. 2016;120:91-107.

13. Renoux L, Dolan MC, Cook CA, Smit NJ, Sikkel PC. Developing an apicomplexan DNA barcoding system to detect blood parasites of small coral reef fishes. J Parasitol. 2017;103(4):366-76.

14. Gjurčević E, Kužir S, Baždarić B, Matanović K, Debelić I, Marino F, et al. New data on Eimeria dicentrarchi (Apicomplexa: Eimeriidae), a common parasite of farmed European sea bass (Dicentrarchus labrax) from the mid-eastern Adriatic. Vet Arh. 2017:87:77-86.

15. Bricknell IR, Bron JE, Bowden TJ. Diseases of gadoid fish in cultivation: a review. ICES J Mar Sci. 2006:63:253-66.

16. Atkins KE, Read AF, Savill NJ, Renz KG, Walkden-Brown SW, Woolhouse ME. Modelling Marek's disease virus (MDV) infection: parameter estimates for mortality rate and infectiousness. BMC Vet Res. 2011;7:70.

17. Sundberg L-R, Ketola T, Laanto E, Kinnula $H$, Bamford JKH, Penttinen R, Mappes J. Intensive aquaculture selects for increased virulence and interference competition in bacteria. Proc R Soc Lond B Biol Sci. 2016; 283:20153069.

18. Kennedy DA, Kurath G, Brito IL, Purcell MK, Read AF, Winton JR, Wargo AR. Potential drivers of virulence evolution in aquaculture. Evol Appl. 2016:9:344-54.

19. Ujvari B, Madsen T, Olsson M. High prevalence of Hepatozoon spp. (Apicomplexa, Hepatozoidae) infection in water pythons (Liasis fuscus) from tropical Australia. J Parasitol. 2004;90:670-2.

20. Kearse M, Moir R, Wilson A, Stones-Havas S, Cheung M, Sturrock S, et al. Geneious basic: an integrated and extendable desktop software platform for the organization and analysis of sequence data. Bioinformatics. 2012;28:1647-9.

21. Katoh K, Standley DM. MAFFT multiple sequence alignment software version 7: improvements in performance and usability. Mol Biol Evol. 2013:30:772-80.
22. Darriba D, Taboada GL, Doallo R, Posada D. jModelTest 2: more models, new heuristics and parallel computing. Nat Methods. 2012;9:772.

23. Bazinet AL, Zwickl DJ, Cummings MP. A gateway for phylogenetic analysis powered by grid computing featuring GARLI 2.0. Syst Biol. 2014;63:812-8.

24. Ronquist F, Teslenko M, van der Mark P, Ayres DL, Darling A, Höhna S, et al. MrBayes 3.2: efficient Bayesian phylogenetic inference and model choice across a large model space. Syst Biol. 2012;61:539-42.

25. Rambaut A, Suchard MA, Xie D, Drummond AJ. Tracer v1.6. 2014; Available from http://tree.bio.ed.ac.uk/software/tracer/.

26. Tamura K, Stecher G, Peterson D, Filipski A, Kumar S. MEGA6: molecular evolutionary genetics analysis version 6.0. Mol Biol Evol. 2013;30:2725-9.

27. Barta JR, Martin DS, Carreno RA, Siddall ME, Profous-Juchelka H, Hozza M, et al. Molecular phylogeny of the other tissue coccidia: Lankesterella and Caryospora. J Parasitol. 2001;87:121-7.

28. Innis CJ, Garner MM, Johnson AJ, Wellehan JFX, Tabaka C, Marschang RE, et al. Antemortem diagnosis and characterization of nasal intranuclear coccidiosis in Sulawesi tortoises (Indotestudo forsteni). J Vet Diagn Investig. 2007;19:660-7.

29. Chapman PA, Owen H, Flint M, Traub RJ, Cribb TH, Mills P. Molecular characterization of coccidia associated with an epizootic in green sea turtles (Chelonia mydas) in South East Queensland, Australia. PLoS One. 2016;11:e0149962.

30. Ogedengbe J, Hanner R, Barta J. DNA barcoding identifies Eimeria species and contributes to the phylogenetics of coccidian parasites (Eimeriorina, Apicomplexa, Alveolata). Int J Parasitol. 2011;41:843-50.

31. Rueckert S, Chantangsi C, Leander B. Molecular systematics of marine gregarines (Apicomplexa) from North-Eastern Pacific polychaetes and nemerteans, with descriptions of three novel species: Lecudina phyllochaetopteri sp. nov., Difficilina tubulani sp. nov. and Difficilina paranemertis sp. nov. Int J Syst Evol Microbiol. 2010;60:2681-90.

32. Rueckert $S$, Villette $P$, Leander B. Species boundaries in gregarine apicomplexan parasites: a case study- comparison of morphometric and molecular variability in Lecudina cf. tuzetae (Eugregarinorida, Lecudinidae). J Eukaryot Microbiol. 2011:58:275-83.

33. Rosado D, Brito J, Harris D. Molecular screening of Hepatozoon (Apicomplexa: Adeleorina) infections in Python sebae from West Africa using $18 \mathrm{~S}$ rRNA gene sequences. Herpetol Notes. 2015;8:461-3.

34. Gestal C, Roch P, Renault T, Pallavicini A, Paillard C, Novoa B, et al. Study of diseases and the immune system of bivalves using molecular biology and genomics. Rev Fish Sci. 2008:16:133-56.

35. Vrba V, Poplstein M, Pakandl M. The discovery of the two types of small subunit ribosomal RNA gene in Eimeria mitis contests the existence of $E$. mivati as an independent species. Vet Parasitol. 2011;183:47-53.

36. Nishimoto Y, Arisue N, Kawai S, Escalante AA, Horii T, Tanabe K, Hashimoto T. Evolution and phylogeny of the heterogeneous cytosolic SSU rRNA genes in the genus Plasmodium. Mol Phyl Evol. 2008;47:45-53.

37. El-Sherry S, Ogedengbe ME, Hafeez MA, Barta JR. Divergent nuclear $18 \mathrm{~S}$ rDNA paralogs in a turkey coccidium, Eimeria meleagrimitis, complicate molecular systematics and identification. Int J Parasitol. 2013:43:679-85.

38. Harris DJ, Borges-Nojosa DM, Maia JP. Prevalence and diversity of Hepatozoon in native and exotic geckos from Brazil. J Parasitol. 2015;101:80-5.

39. Borges-Nojosa DM, Borges-Leite MJ, Maia JP, Zanchi-Silva D, da Rocha BR, Harris DJ. A new species of Hepatozoon miller, 1908 (Apicomplexa: Adelerina) from the snake Philodryas nattereri Steindachner (Squamata: Dipsadidae) in northeastern Brazil. Syst Parasitol. 2017:94:65-72.

40. Paperna I. Sporozoan infection in cultured Sparus aurata L. and wild Siganus luridus. Ann Parasitol Hum Comp. 1979:54:385-92.

41. Paperna I, Sabnai I. A coccidian cyst stage in musculature of Liza subviridis (Mugilidae). Z Parasitenkd. 1982;68:161-70.

42. Overstreet R, Hawkins W, Fournie J. The coccidian genus Calyptospora n. g. and family Calyptosporidae n. fam. (Apicomplexa), with members infecting primarily fishes. J Protozool. 1984;31:332-9.

43. Merella P, Garippa G, Salati F. Parasites of cage cultured European seabass Dicentrarchus labrax and gilthead seabream Sparus aurata from Sardinia (western Mediterranean): first results. Parassitologia. 2006;48:290.

44. Daoudi F, Marques A. Eimeria bouixi n. sp. and Eimeria dicentrarchi n. Sp. (Sporozoa - Apicomplexa) parasites from the fish Dicentrarchus labrax Linné 1758 in Languedoc France. Ann Sci Nat Zool Biol Anim. 1987:8:237-42.

45. Santos M. Observations on the parasitofauna of wild sea bass (Dicentrarchus labrax L.) from Portugal. Bull Eur Assoc Fish Pathol. 1996;16:77-9.

46. Gestal C, Azevedo C. Ultrastructural aspects of hepatic coccidiosis caused by Goussia lusca n. sp. (Apicomplexa: Coccidia) infecting Trisopterus luscus (Gadidae) from the NE Atlantic Ocean. Dis Aquat Org. 2006;71:25-31. 
47. Abollo E, Calvo M, Pascual S. Hepatic coccidiosis of the blue whiting, Micromesistius poutassou (Risso), and horse mackerel, Trachurus trachurus (L.) from Galician waters. J Fish Dis. 2001;24:335-43.

48. Costa G, MacKenzie K. Histopathology of Goussia clupearum (Protozoa: Apicomplexa: Coccidia) in some marine fish from Scottish waters. Dis Aquat Org. 1994;18:195-202.

49. Diouf M, Ferrer JM, Benajiba MH. Structure and population dynamics of Goussia cruciata (Thélohan, 1892), hepatic coccidiosis agent of the horse mackerel, Trachurus trachurus (Linnaeus, 1758) from the Moroccan Mediterranean coasts. Bull Eur Assoc Fish Pathol. 2005;25:2-8.

50. Gestal C, Azevedo C. Ultrastructure of Goussia cruciata (Apicomplexa: Coccidia) infecting the liver of the horse mackerel, Trachurus trachurus (L.), from Ibero-Atlantic waters. J Fish Dis. 2005;28:125-32.

51. Kalfa-Papaioannou AM, Athanassopoulou-Raptopoulou F. Incidence of coccidiosis in horse-mackerel (Trachurus trachurus, T. mediterraneus, T. picturatus) and sardines (Clupea pilchardus) from the North Aegean Sea. Zentralb Veterinärmed B. 1984;31:530-6.

52. Diouf M, Toguebaye BS. Eimeria spari n. sp.., (Apicomplexa, Emeriidae) parasite de Sparus caeruleostictus (Valenciennes, 1830), (Poisson, Sparidae) des cotes sénégalaises. Parasite. 1996;3:351-5.

53. Amemiya CT, Alfoldi J, Lee AP, Fan S, Philippe H, MacCallum I, Braasch I, Manousaki T, Schneider I, Rohner N, et al. The African coelacanth genome provides insights into tetrapod evolution. Nature. 2013;496:311-6.

54. Edgcomb V, Orsi W, Bunge J, Jeon S, Christen R, Leslin C, et al. Protistan microbial observatory in the Cariaco Basin, Caribbean. I. Pyrosequencing vs Sanger insights into species richness. ISME J. 2011;5:1344-56.

55. Megía-Palma R, Martínez J, Nasri I, Cuervo JJ, Martín J, Acevedo I, et al. Phylogenetic relationships of Isospora, Lankesterella, and Caryospora species (Apicomplexa: Eimeriidae) infecting lizards. Org Div Evol. 2016;16:275-88.

\section{Submit your next manuscript to BioMed Central and we will help you at every step:}

- We accept pre-submission inquiries

- Our selector tool helps you to find the most relevant journal

- We provide round the clock customer support

- Convenient online submission

- Thorough peer review

- Inclusion in PubMed and all major indexing services

- Maximum visibility for your research

Submit your manuscript at www.biomedcentral.com/submit 